\title{
PREDICTIVE MONITORING OF SECONDARY EPIDEMIC WAVES OF COVID-19 IN IRAN, RUSSIA AND OTHER COUNTRIES
}

\section{Kovriguine DA' ${ }^{1}$ Nikitenkova SP${ }^{2} \otimes$}

${ }^{1}$ Nizhny Novgorod State Technical University n.a. R.E. Alekseev, Nizhny Novgorod, Russia

${ }^{2}$ National Research Lobachevsky State University of Nizhny Novgorod, Nizhny Novgorod, Russia

In the last decade of April 2020, the second coronavirus epidemic wave in Iran has bloomed. The new wave has started in the vicinity of the critical point, marked by approximately 44,000 infections, where the rate of increase of the primary epidemic that appeared in Iran in mid-February 2020 was the highest. Today, this secondary wave almost has doubled the peak of the primary, and, passing the epidemic threshold of about 70,000 total cases in early June, generated the new third epidemic wave developing unpredictably and dynamically. The purpose of this work was to call into use a simple dynamical system represented by the discrete logistic equation with unknown parameters to predict secondary waves using the official statistical data. The mathematical modelling reveals the secondary epidemic waves in Sweden, the United States, Ukraine, Serbia, Romania, Czech Republic, Portugal, Luxembourg, Poland, and Ecuador. Also, the second waves appear in Russia and other countries. Despite many individual differences in the epidemic spread in different countries, we have traced regularity in the rise of secondary waves. The beginning of each new wave, if focusing on the number of total cases, practically coincides with the time of the maximum growth rate of the previous early epidemic. Thus, the passing through the threshold of the current wave should be the most responsible for strict observance of the rules of self-isolation and other sanitary standards.

Keywords: COVID-19, pandemic, monitoring, forecasting, second wave, logistic equation

Author contribution: Kovriguine DA — research planning, literature analysis, data analysis and interpretation, manuscript preparation; Nikitenkova SP — research planning, literature analysis, data analysis and interpretation, manuscript preparation.

$\triangle$ Correspondence should be addressed: Svetlana P. Nikitenkova

Gagarina, 23, Nizhny Novgorod; 603950; snikitenkova@gmail.com

Received: 13.07.2020 Accepted: 02.08.2020 Published online: 13.08.2020

DOI: $10.24075 /$ brsmu.2020.046

\section{ПРОГНОЗНЫЙ МОНИТОРИНГ ВТОРЫХ ВОЛН ЭПИДЕМИИ СОVID-19 В ИРАНЕ, РОССИИ И ДРУГИХ СТРАНАХ}

Д. А. Ковригин ${ }^{1}$, С. П. Никитенкова ${ }^{2}$

${ }^{1}$ Нижегородский государственный технический университет имени Р. Е. Алексеева, Нижний Новгород, Россия

${ }^{2}$ Национальный исследовательский Нижегородский государственный университет имени Н. И. Лобачевского, Нижний Новгород, Россия

В последней декаде апреля 2020 г. в Иране поднялась вторая волна новой эпидемии коронавирусной инсекции. Новая волна возникла в окрестности пороговой точки, отмеченной примерно 44000 случаев заражения, где скорость нарастания первой волны эпидемии, появившейся в Иране в середине февраля 2020 г., была максимальна. Вторая волна почти вдвое превысила пик первой, и, в свою очередь, в начале июня, преодолев новый порог, составляющий около 70000 случаев заражения, породила третью волну, развивающуюся динамично и непредсказуемо. Целью работы было провести для выявления вторых волн обработку официальных статистических данных на основе простейшей динамической системы, представленной дискретным логистическим уравнением. Изучение этой математической модели показало, что вторые волны эпидемии уже можно наблюдать в Швеции, США, Украине, Сербии, Румынии, Чехии, Эквадоре, Португалии, Люксембурге, а также в России и других странах. Несмотря на индивидуальные различия в динамике распространения эпидемии в отдельных странах, закономерность подъема вторых волн остается той же: начало новой волны, если ориентироваться по количеству общих случаев заражения, практически совпадает со временем достижения максимальной скорости роста предыдущей эпидемии. Это означает, что в период перехода через критический порог текущей волны необходима наибольшая ответственность с точки зрения неукоснительного соблюдения правил самоизоляции и иных санитарных норм.

Ключевые слова: COVID-19, пандемия, мониторинг, прогнозирование, вторая волна, логистическая модель

Вклад авторов: Д. А. Ковригин - планирование исследования, анализ литературы, анализ и интерпретация данных, подготовка черновика и финального варианта статьи; С. П. Никитенкова - планирование исследования, интерпретация данных, подготовка черновика и финального варианта статьи.

$\triangle$ Для корреспонденции: Светлана Павловна Никитенкова

пр. Гагарина, д. 23, г. Нижний Новгород, 603950; snikitenkova@gmail.com

Статья получена: 13.07.2020 Статья принята к печати: 02.08.2020 Опубликована онлайн: 13.08.2020

DOI: $10.24075 /$ vrgmu.2020.046

The first epidemic wave in Iran had attracted the attention of observers and researchers by a relatively high rate of overall infections [1-5]. The processing of official statistics to predict the second waves based on a logistic model showed that the first wave was only a harbinger of the spread of a new, higher wave of the epidemic, which had already swept through this country and gave rise to the third wave in early June. (We interpret an epidemic wave as the process either of transferring and spreading the infection to a new territory with a new population or returning to the old places partially or completely have recovered after the primary epidemic.)
Recently, the secondary waves of the epidemic have started in Sweden, the United States, Ukraine, Serbia, Romania, Czech Republic, Ecuador and some other countries. As yet, there are no rigorous mathematical models to shed light, in particular, on those critical points at which the secondary epidemic appears (we understand a strict theory as axiomatics based on the maximum principle. Any epidemic naturally "strives" to occupy the entire territory and cover the entire "available" population).

Today, there are more and more messages in the media about the expectation of second waves of the epidemic in 


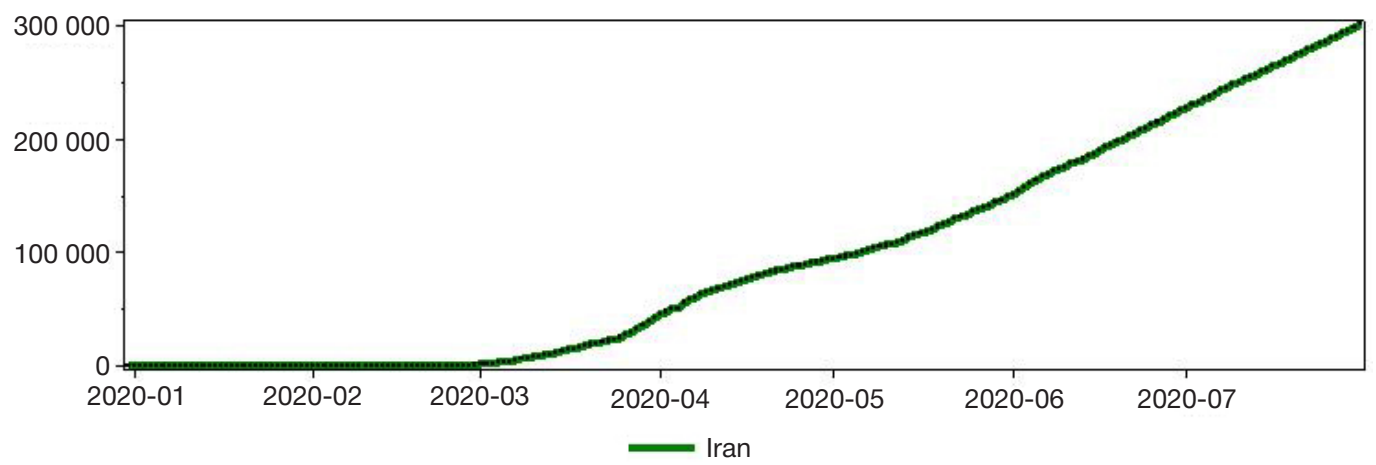

Fig. 1. Epidemic history of Iran. The solid line marks the total officially reported cases by day since the beginning of the epidemic in this country

Russia. However, this acute question remains open without a rigorous analysis of the input data.

The purpose of this work is to describe the secondary epidemic waves mathematically. We have chosen a simple dynamic logistic system with the unknown parameters which are determined by the official data (data source: https://covid. ourworldindata.org/). The aim is to identify the most favourable conditions for the occurrence of secondary waves.

\section{METHODS}

We use the tabular autocorrelation dependencies $N_{i+1}=f_{c}\left(N_{i}\right)$, to construct the dynamic system. Here, $N_{i}$ is the number of total cases, accumulated to the date $i$, in the country number $c$. The least-squares method determines the polynomial approximations of tabular functions $f_{c}$, denoted as $F_{\text {c }}$.

Numerical experiments confirm the sufficiency of the quadratic approximation of functions $f_{s}$ from the argument $N$ that provides a logistic model. So, we have got the analytic point mapping having the right-hand side $F_{c}\left(N_{i}\right)=a_{0}+a_{1} N_{i}+a_{2} N_{i}^{2}$, where $a_{i}$ are the parameters determined from the tables (data source: https://covid.ourworldindata.org/). The transition time between the states $N_{i}$ and $N_{i+1}$ takes a day. The logistic mapping approaches the steady-state $N=N^{*}$, as a positive solution to the equation $N^{*}=a_{0}+a_{1} N^{*}+a_{2} N^{* 2}$. The steady-state $N^{*}$ corresponds to almost zero dynamic increase in disease [6]. At the time of achieving this stable equilibrium, the logistic equation is no longer sufficient to describe the evolution of the disease in a developed human society. The fate of infected people depends on the quality of quarantine measures, medical care, etc.

We suppose that the logistic equation describes the temporal evolution of each wave of the epidemic adequately in countries with high-quality statistics. After processing the

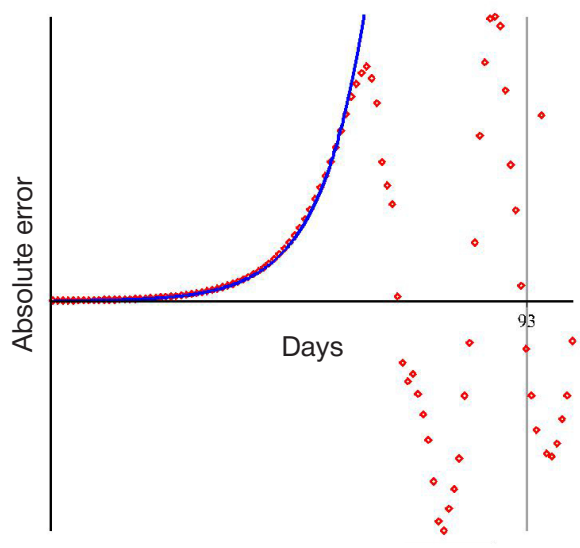

- Exponential fit data, we select results using simple criteria and standard Maple software (Maplesoft; Canada).

There is no doubt that, theoretically, the epidemic can develop for the second and third time, etc. in an unpredictable way, if we neglect the appropriate anti-epidemic measures. As calculations show, the second wave of the epidemic, as a rule, rises after passing the critical point, which is the inflexion point of the logistic curve [7-9]. The linear equation $a_{1}+2 a_{2} N=1$ defines the threshold $N$.

In the case of secondary epidemic waves, we use the same dynamic system for calculations. The described above procedure calculates the current parameters $a_{1}$ using a new, appropriately decomposed input data set. We remove the already calculated data, provided by the logistic curve of the first wave, from the old input data set. The computation process continues until the input data will represent a superposition of various individual logistic curves.

There is no doubt that all input is perfect. In case of failure of the specified decomposition of the input data, we decide that the algorithm described above does not work, and omit such input data from the analysis. Note that the idea of such an algorithm is not new - it first appeared in the socio-economic sciences [10].

There are examples of its successful application in mathematical biophysics [11]. In the context of the current pandemic, the work [12] is of interest. The authors take into account the secondary wave to adjust the results of their previous work [13].

\section{RESULTS}

Consider an example of the epidemic history of the countries that did not escape the risk of the second wave. Let it be the most vividly manifested country in this respect, Iran, the history of the epidemic of which is shown in Fig. 1.

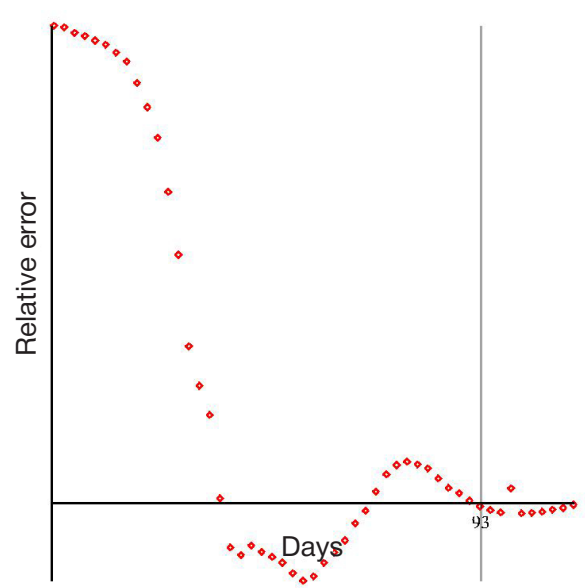

Fig. 2. Absolute and relative errors of forecasting. On the left, the solid line traces the exponential approximation of a discrepancy between actual and forecast data 
The graph above shows that around the middle of April, the second wave of the epidemic rose in Iran. The epidemic spread is still very far from complete since the growth of the third wave has been observed from the beginning of June. Notice that the mentioned above algorithm decomposing the secondary waves could not recognize the third wave, and interpreted the data as statistical errors for two or three weeks ago.

Let us now try identifying the first wave of the epidemic in Iran by estimating the absolute and relative errors between the input and forecast data, which are described by the logistic curve. The mean squared error is minimal if the first wave reaches the threshold at 93 days from the start of the epidemic (Fig. 2). Note that the search for the minimum uses a priori dynamic data analysis that should not have to cover the entire history of the epidemic.

Figure 2 on the left displays that the input data, starting from the very beginning of the epidemic and up to the point of the maximum absolute error, obey the exponential dependence shown by the solid line. This fact is not a revelation: the behaviour of real data over time shown in graphs is not a specific feature of the history of the epidemic in Iran only. The authors of some works on the problem of the pandemic have noticed such a pattern, explaining this regular exponential component with useful medical intervention in the early epidemic.

However, it is easier to assume that this unavoidable regular error is due only to the specifics of data monitoring. Moreover, the analytical approximation of the input data set continues further, starting from the point of maximum absolute error up to the inflexion point using the power function $[14,15]$.

We have studied this regular monitoring error by analyzing the epidemic history in some countries of Western Europe, which had reached the first epidemic peak [16]. Notice that to reach the epidemic peak is necessary to apply a posteriori data analysis that leads to the same results that we obtain in the case of the dynamic a priori analysis. We have analytically revealed the regular component of the monitoring error. This error explained the reason for the failure of a priori mathematical forecasting of probable epidemic events in various countries of the world, undertaken in numerous studies. The statistical data processing of almost all countries that have reached the epidemic peak showed that the regular monitoring error is subject to a simple pattern: the higher the epidemic peak, the greater the time delay of the monitoring data compared to the forecast.

Let us identify the primary epidemic wave in Iran, following a priori approach. Thus, we believe that the discrete logistic equation $N_{i+1}=1,118 N_{i}-1,344 \times 10^{-6} N_{i}^{2}$ adequately describes the first wave. Notice that the parameters of the first wave no longer change throughout the epidemic when the second wave appears. Figure 3 shows the solution to this equation.

Now we decompose the input data taking into account that the logistic curve shown in the above figure adequately approximates the early history of the epidemic. At the next stage of processing the input data, we identify the second epidemic wave. Calculations are performed recursively in the same way as used above. The discrete logistic equation also adequately describes the second wave, but with a different right-hand side: $N_{i+1}=1,056 N_{i}-3,202 \times 10^{-7} N_{i}^{2}$. The parameters of this equation slowly change in time until the formation of a sufficient height of the third wave. Figure 4 displays this decomposition graphically.

This figure displays that the residual data, corresponding to the secondary and tertiary waves, can no longer represent a single logistic line. Thus the epidemic in Iran has become a continuous wave cascade, the most unfavourable for combating the epidemic. In any case, Iran cannot avoid the third epidemic wave.

We can repeat the above arguments and calculations using other data on the epidemic history in other countries, for example, Sweden. The first epidemic wave of in Sweden, compared with Iran, had a relatively small height with the threshold of about 15,000 registered cases reached in 115 days after the start of the epidemic (Fig. 5). Also, this

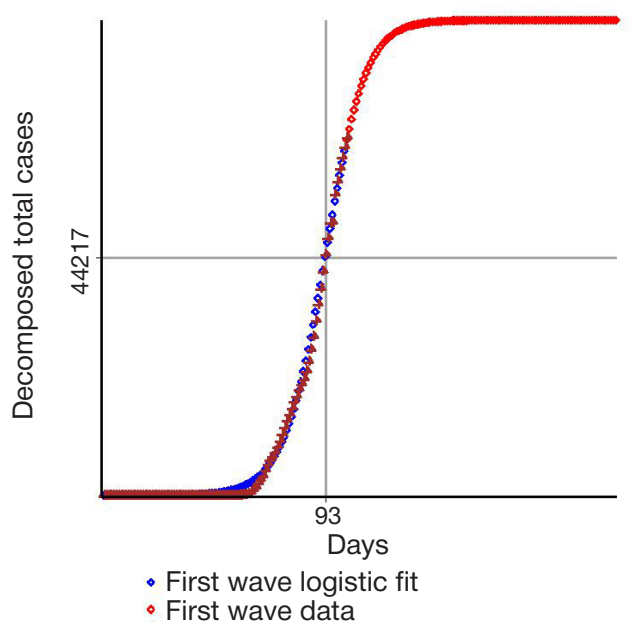

Fig. 3. Profile of the first wave of the epidemic in Iran. The extrapolation points reach the epidemic peak of the first wave

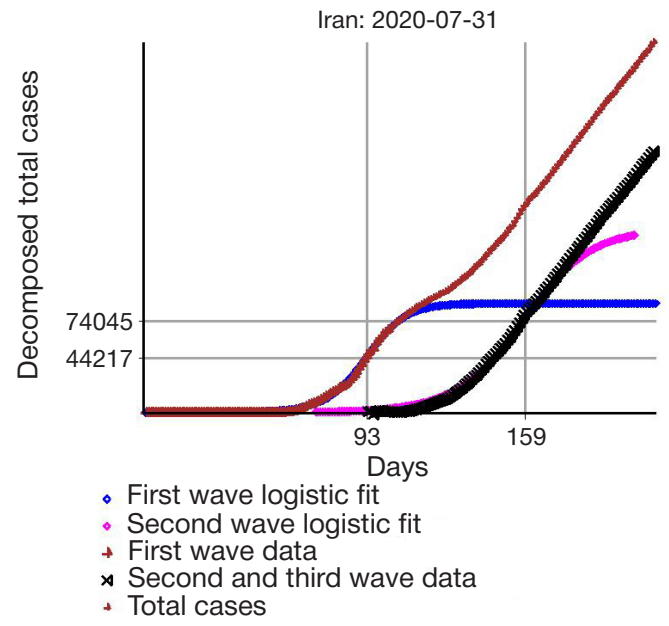

Fig. 4. Superposition of two logistic lines both of the first and second waves. We can observe the beginning of the growth of the tertiary wave

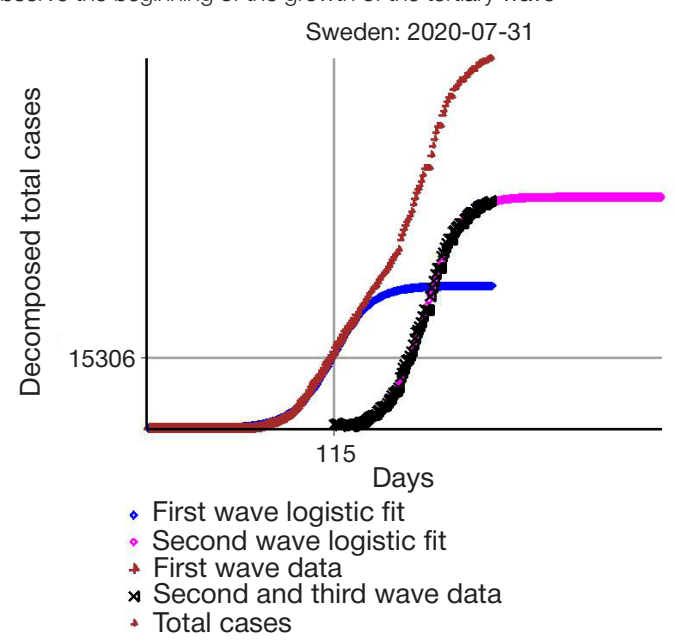

Fig. 5. Decomposition of the full input data by total cases in Sweden as a superposition of two logistic lines of the first and second waves 
illustration explains the input-data decomposition for detecting the secondary waves.

Figure 6 shows that a situation similar to that in Iran takes place in Ukraine.

In comparison with the other countries, the secondary epidemic wave in the United States has got a gigantic scale, growing exponentially (Fig. 7).

Today, on the World Wide Web and television, there are more and more messages about the expectation of a second wave of the epidemic in Russia. These reports, as a rule, are based on speculation, which leaves open a burning question: should or not be the second wave of the epidemic in Russia?

Using our mathematical tools, we have found that the second epidemic wave in Russia had already risen in the first half of May. The height of this wave is about half the primary wave. The third wave has started in Russia at the end of June. Figure 8 represents a decomposition of the epidemic history in Russia as a superposition of the primary and secondary waves.

The appearance of the second wave in different countries possesses similar features despite some differences in the epidemic spread. We have admitted regularity in the rise of the second waves. These waves appear when passing through the critical point of the epidemic threshold of the current wave.

Pragmatically, passing through the threshold of a new wave should be the most responsible in terms of strict observance of the rules of self-isolation and other sanitary standards. The secondary waves of the epidemic are insidious in that they do not appear immediately but after a sufficiently long time. For example, in Iran, the second wave significantly showed itself in no less than 60 days.

\section{DISCUSSION}

There are several different mechanisms, each of which can generate secondary waves in acute infectious disease. The first two mechanisms are due to the direct viral transmission and a change in its behaviour, which favours the emergence of additional ways of its spread. The third one is associated with the heterogeneity of the population. A new wave either occupates new territories and population or rolls over the previous places again. The fourth item is a mutation in the virus that causes delayed susceptibility to infection in humans. One more mechanism is weakening immunity. There is no problem to take these mechanisms into account in complex mathematical models to simulate secondary waves [17]. We may add that secondary waves are, not least, a consequence of the lax compliance with quarantine and sanitary rules by people who trust rumours and consume unreliable mass information.

In this work, the authors abandoned multivariate models, which, in ideal implementation, are designed to study the impact, for example, of border control at the beginning of an outbreak, predicting the timing of self-isolation, assessing the required amount of available drugs, and others. Indeed, the practice of recent months has shown that the well-tested and widely known mathematical methods, directly used to describe future events of the spread of the epidemic by processing the available statistical data, have demonstrated ineffectiveness.

We know the well-known logistic equation adequately describes the epidemic evolution. However, neither various versions of this mathematical model nor modifications of the logistic equation demonstrate usefulness. In any case, the simulation gives a satisfactory result only on a small-time horizon, within one or two weeks [18].

If so, then we are dealing with not predictive, but with monitoring models, which, for all their value, are still useless for developing medium-term and strategic action plans to overcome the pandemic [19]. Other promising predictive technologies based on graph theory [20], percolation theory [21], and stochastic processes [22] turned out to be too clumsy or incapable to produce a clear and concrete result on an urgent issue. In other words, the available forecast methods have demonstrated helpless when solving the problem.

There is a paradox. On the one hand, it could seem that everything about the dynamics of the pandemic is known

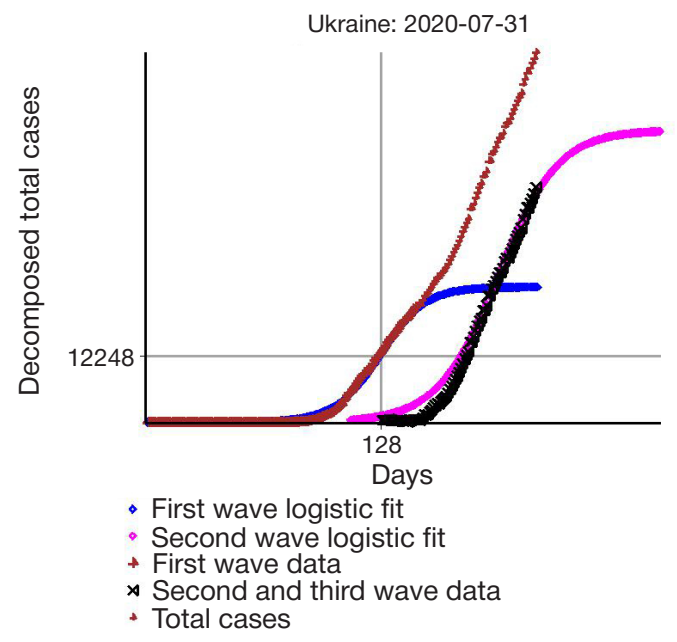

Fig. 6. Decomposition of the input data by total cases in Ukraine

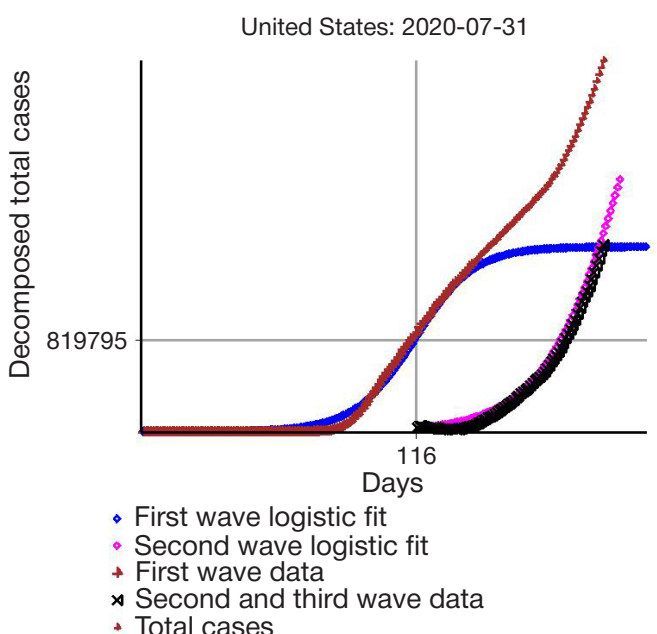

Fig. 7. Secondary epidemic wave in the United States Russia: 2020-07-31

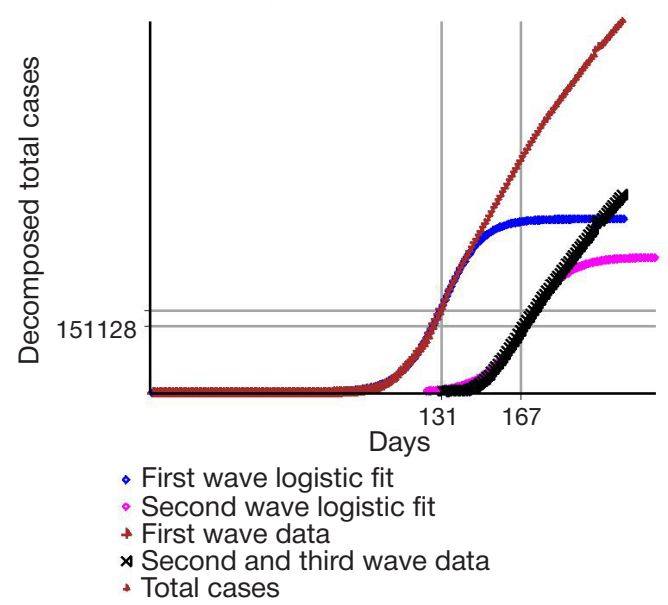

Fig. 8. Sum of two logistic lines of the first and second epidemic waves in Russia 
qualitatively in advance. On the other hand, standard methods cannot provide an adequate prediction.

Let us try to shed light on the main reasons for such a failure and try to formulate the principles for overcoming the current situation. First of all, note that, in contrast to the experimental data, say, in physical experiments, data on the epidemic situation cannot be redundant, but only insufficient. Indeed, it is difficult to imagine a situation where redundant data regularly appears in the monitoring fixing the total number of newly detected cases since the case is too delicate to allow such sloppiness. It is natural to expect that the data has a lack of information. Thus, we can postulate that the regular error describes some deficit in the data. Indeed, we can obtain a comprehensive epidemic data only a posterior. However, a priori analysis requires to identify this regular error using the statistical data of those countries which already have passed the epidemic peak.

We had managed to find the specified regular component of the error inherent in many countries of the world in monitoring the spread of the current pandemic in terms of exponential and power-law approximating functions. This error influences the forecasting of epidemic events critically. However, statistical data of countries have reached an epidemic peak demonstrate the analytical regularity in the virtual time delay. This fact allows us to pose the following question. Is a country that already has passed the threshold close to the peak epidemic or is still far from it?

The regular error of monitoring causes failures of a priori mathematical modelling [16]. We may point out that the predicted and real data, as a rule, practically coincide from the threshold to the peak of the epidemic. The explanation is simple: when crossing the inflexion point, the growth rate of registered infections decreases while the maximum effort is involved in solving the monitoring problem.

Thus, we have decided to limit ourselves to the simplest logistic model in this paper. On the one hand, this model requires a minimum of information to construct it. We need to know the initial number of cases, the final peak number, and the time from the beginning of the epidemic to its peak.
On the other hand, we must understand that the monitoring quality, first of all, determines the reliability of the model, not the number of unknown parameters that we should find out from the input data. In particular, the conservatism of the parameters of the logistic curves for the primary waves confirms the model reliability while the parameters of the current wave slowly change in time because of the indicated natural imperfection of the input data.

\section{CONCLUSION}

This text has focused on the appearance of the second epidemic wave in Iran, Sweden and the United States, Ukraine, and Russia. The analysis of the input data by the total cases shows that the most favourable time for the emergence of secondary waves is the critical point in which the rate of the epidemic increase approaches maximum. The pass of the threshold of the new epidemic wave should be the most responsible in terms of strict observance of the rules of selfisolation and other sanitary standards.

The mathematical model allows detecting the secondary waves much earlier than passively observing the epidemic history. An example is the not entirely obvious second wave in Russia, which arose in early May, and which gave rise to the third wave of the epidemic at the end of June. Nonetheless, today, we desire that Russia is still able to avoid the fourth epidemic wave if combating the epidemic. Iran also has such an opportunity.

The algorithm for studying the secondary waves represents a recursive decomposition of the input data to a set of different logistic curves, the parameters of which, unknown in advance, the calculation process determines. At the first step, we check the possibility of adequate approximation of the input data by a single logistic curve. If success, we attempt to identify the second logistic wave, etc.

Logistics decomposition in many features is similar to the well-known Fourier method or wavelet analysis. However, in our case, the decomposition algorithm does not end with a result if the input data is inappropriate.

\section{References}

1. Moftakhar L, Mozhgan SEIF, Safe MS. Exponentially Increasing Trend of Infected Patients with COVID-19 in Iran: A Comparison of Neural Network and ARIMA Forecasting Models. Iranian Journal of Public Health. 2020; 49: 92-100.

2. Tran TT, Pham LT, Ngo QX. Forecasting epidemic spread of SARSCoV-2 using ARIMA model (Case study: Iran). Global Journal of Environmental Science and Management. 2020; 6 (Special Issue (Covid-19)): 1-10.

3. Zareie B, Roshani A, Mansournia MA, Rasouli MA, Moradi G. A model for COVID-19 prediction in Iran based on China parameters. 2020; medRxiv.

4. Ahmadi A, Fadai Y, Shirani M, Rahmani F. Modeling and forecasting trend of COVID-19 epidemic in Iran until May 13, 2020. Medical Journal of The Islamic Republic of Iran (MJIRI). 2020; 34 (1): 183-95.

5. Li L, Yang Z, Dang Z, Meng C, Huang J, Meng H, Wang D, Chen G, Zhang J, Peng H, Shao Y. Propagation analysis and prediction of the COVID-19. Infectious Disease Modelling. 2020; 5: 282-92.

6. Nejmark Yul. Matematicheskie modeli v estestvoznanii i tehnike. N. Novgorod: Izd-vo Nizhegorodskogo universiteta im. N. I. Lobachevskogo. 2004; 401 s. Russian.

7. Source code Maple-18. Available from: https://kovriguineda. ucoz.ru/COVID-19/COVID-19-Iran.mw.

8. Source code Maple-18. Available from: https://kovriguineda.

ucoz.ru/COVID-19/COVID-19-Russia.mw.

9. Source code Maple-18. Available from: https://kovriguineda. ucoz.ru/COVID-19/COVID-19-Ukraine.mw.

10. Meyer P. Bi-logistic growth. Technological forecasting and social change. 1994; 47 (1): 89-102.

11. Lavrova Al, Postnikov EB, Manicheva OA, Vishnevsky Bl. Bi-logistic model for disease dynamics caused by Mycobacterium tuberculosis in Russia. Royal Society open science. 2017; 4 (9): 171033.

12. Dattoli $\mathrm{G}$, et al. On the evolution of covid-19 in Italy: a follow up note. Available from: arXiv preprint arXiv:2003. 2020; 12667.

13. Dattoli G, Di Palma E, Licciardi S, Sabia E. A Note on the Evolution of Covid-19 in Italy, arXiv:2003.08684v1 [q-bio.PE], 19 Mar 2020.

14. Bhattacharya S, Islam MM, De A. Search for the trend of COVID-19 infection following Farr's law, IDEA model and power law. medRxiv. 2020; Available from: https://doi.org/10.1101/202 0.05.04.20090233.

15. Singer HM. The COVID-19 pandemic: growth patterns, power law scaling, and saturation. medRxiv. 2020; Available from: https:// doi.org/10.1101/2020.07.12.20152140.

16. Nikitenkova SP, Kovriguine DA. It's the very time to learn a pandemic lesson: why have predictive techniques been ineffective when describing long-term events? medRxiv. 2020; Available from: https://doi.org/10.1101/2020.06.01.20118869. 
17. Mummert A, et al. A perspective on multiple waves of influenza pandemics. PloS one. 2013; 8 (4): e60343.

18. Lakman IA, Agapitov AA, Sadikova LF, Chernenko OV, Novikov SV, Popov DV, i dr. Vozmozhnosti matematicheskogo prognozirovanija koronavirusnoj infekcii $v$ Rossijskoj Federacii. Arterial'naja gipertenzija. 2020; 26 (3): 288-94. Dostupno po ssylke: https:// doi.org/10.18705/1607-419X-2020-26-3-288-294. Russian.

19. Holmdahl I, Buckee C. Wrong but useful - what covid-19 epidemiologic models can and cannot tell us. N Engl J Med. 2020
May 15. DOI: 10.1056/NEJMp2016822.

20. Ivannikov YuG, Ogarkov PI. Opyt matematicheskogo komp'juternogo prognozirovanija jepidemij grippa dlja bol'shih territorii. Zhurnal infektologii. 2012; 4 (3): 101-06. Available from: https://doi. org/10.22625/2072-6732-2012-4-3-101-106. Russian.

21. Luo Y, Schaposnik LP. Minimal percolating sets for mutating infectious diseases. Physical Review Research. 2020; 2 (2): 023001.

22. de Arruda GF, Petri G, Moreno Y. Social contagion models on hypergraphs. Physical Review Research. 2020; 2 (2): 023032.

\section{Литература}

1. Moftakhar L, Mozhgan SEIF, Safe MS. Exponentially Increasing Trend of Infected Patients with COVID-19 in Iran: A Comparison of Neural Network and ARIMA Forecasting Models. Iranian Journal of Public Health. 2020; 49: 92-100.

2. Tran TT, Pham LT, Ngo QX. Forecasting epidemic spread of SARSCoV-2 using ARIMA model (Case study: Iran). Global Journal of Environmental Science and Management. 2020; 6 (Special Issue (Covid-19)): 1-10.

3. Zareie B, Roshani A, Mansournia MA, Rasouli MA, Moradi G. A model for COVID-19 prediction in Iran based on China parameters. 2020; medRxiv.

4. Ahmadi A, Fadai Y, Shirani M, Rahmani F. Modeling and forecasting trend of COVID-19 epidemic in Iran until May 13, 2020. Medical Journal of The Islamic Republic of Iran (MJIRI). 2020; 34 (1): 183-95.

5. Li L, Yang Z, Dang Z, Meng C, Huang J, Meng H, Wang D, Chen G, Zhang J, Peng H, Shao Y. Propagation analysis and prediction of the COVID-19. Infectious Disease Modelling. 2020; 5: 282-92.

6. Неймарк Ю. И. Математические модели в естествознании и технике. Н. Новгород: Изд-во Нижегородского университета им. Н. И. Лобачевского, 2004; 401 с.

7. Код Maple-18. Доступно по ссылке: https://kovriguineda.ucoz. ru/COVID-19/COVID-19-Iran.mw.

8. Код Maple-18. Доступно по ссылке: https://kovriguineda.ucoz. ru/COVID-19/COVID-19-Russia.mw.

9. Код Maple-18. Доступно по ссылке: https://kovriguineda.ucoz. ru/COVID-19/COVID-19-Ukraine.mw.

10. Meyer P. Bi-logistic growth. Technological forecasting and social change. 1994; 47 (1): 89-102.

11. Lavrova Al, Postnikov EB, Manicheva OA, Vishnevsky BI. Bi-logistic model for disease dynamics caused by Mycobacterium tuberculosis in Russia. Royal Society open science. 2017; 4 (9): 171033.

12. Dattoli $\mathrm{G}$, et al. On the evolution of covid-19 in Italy: a follow up note. Available from: arXiv preprint arXiv:2003. 2020; 12667.

13. Dattoli G, Di Palma E, Licciardi S, Sabia E. A Note on the Evolution of Covid-19 in Italy, arXiv:2003.08684v1 [q-bio.PE], 19 Mar 2020.

14. Bhattacharya S, Islam MM, De A. Search for the trend of COVID-19 infection following Farr's law, IDEA model and power law. medRxiv. 2020; Available from: https://doi.org/10.1101/202 0.05 .04 .20090233

15. Singer HM. The COVID-19 pandemic: growth patterns, power law scaling, and saturation. medRxiv. 2020; Available from: https:// doi.org/10.1101/2020.07.12.20152140.

16. Nikitenkova SP, Kovriguine DA. It's the very time to learn a pandemic lesson: why have predictive techniques been ineffective when describing long-term events? medRxiv. 2020; Available from: https://doi.org/10.1101/2020.06.01.20118869.

17. Mummert $A$, et al. A perspective on multiple waves of influenza pandemics. PloS one. 2013; 8 (4): e60343.

18. Лакман И. А., Агапитов А. А., Садикова Л. Ф., Черненко О. В., Новиков С. В., Попов Д. В. и др. Возможности математического прогнозирования коронавирусной инфекции в Российской Федерации. Артериальная гипертензия. 2020; 26 (3): 28894. Доступно по ссылке: https://doi.org/10.18705/1607419X-2020-26-3-288-294.

19. Holmdahl I, Buckee C. Wrong but useful - what covid-19 epidemiologic models can and cannot tell us. N Engl J Med. 2020 May 15. DOI: 10.1056/NEJMp2016822.

20. Иванников Ю. Г., Огарков П. И. Опыт математического компьютерного прогнозирования эпидемий гриппа для больших территорий. Журнал инфектологии. 2012; 4 (3): 101-06. Available from: https://doi.org/10.22625/2072-67322012-4-3-101-106.

21. Luo Y, Schaposnik LP. Minimal percolating sets for mutating infectious diseases. Physical Review Research. 2020; 2 (2): 023001.

22. de Arruda GF, Petri G, Moreno Y. Social contagion models on hypergraphs. Physical Review Research. 2020; 2 (2): 023032. 


\title{
REHABILITATION OF PATIENTS WITH CEREBRAL PALSY USING HAND EXOSKELETON CONTROLLED BY BRAIN-COMPUTER INTERFACE
}

\author{
Bobrov $\mathrm{PD}^{1,2}$, Biryukova $\mathrm{EV}^{1,2}$, Polyaev BA' $\mathrm{B}^{1}$ Lajsheva $\mathrm{OA}^{1,3}$, Usachjova $\mathrm{EL}^{3}$, Sokolova $\mathrm{AV}^{3}$, Mihailova $\mathrm{Dl}^{3}$, Dement'eva $\mathrm{KN}^{3}$, Fedotova $\mathrm{IR}^{2}$
}

${ }_{1}^{1}$ Pirogov Russian National Research Medical University, Moscow, Russia

2 Institute of Higher Nervous Activity and Neurophysiology of RAS, Moscow, Russia

${ }^{3}$ Russian Children's Clinical Hospital of Pirogov Russian National Research Medical University, Moscow, Russia

\begin{abstract}
Cerebral palsy (CP) is one of the most severe central nervous system diseases in childhood associated with motor impairment. The study was aimed to assess the efficiency of the complex comprising brain-computer interface $(\mathrm{BCl})$ and hand exoskeleton as an instrument for the motor function recovery in patients with $\mathrm{CP}$ complementing the essential therapy. The Fugl-Meyer Assessment scale, ARAT test and Jebsen-Taylor function test were used in 14 children and adolescents for the motor function improvement assessment after the therapy complemented by 7-10 BCl-exoskeleton based procedures. The EEG mu-rhythm sources properties during the motor imagery $\mathrm{BCl}$ control were studied. After the procedures completion, the significant improvement of the Fugl-Meyer Assessment scale score (7 (2; 11) for hand active movements; $4.5(1 ; 6)$ for proximal arm and $2.5(0 ; 5)$ for hand), ARAT test score $(7.5(1 ; 31)$ for total score, 1.5 (0; 12$)$ for grasp movement and $1.5(0 ; 8)$ for grip movement), as well as significantly different from the zero execution time reduction in three out of seven Jabsen-Taylor function test items $(-1(-4.13 ; 0.25)$ for simulated feeding; $-1(-2 ; 0)$ for moving light and heavy cans) were identified. The average BCl detection level was $0.51(0.45 ; 0.54)(\max =0.70)$. In most EEG recordings the mu-rhythm sources were detected, both for intact and affected hemispheres. The mu-rhythm desynchronization associated with motor imagery was observed, significantly affecting the $\mathrm{BCl}$ accuracy. The results obtained indicate that the use of $\mathrm{BCl}$-exoskeleton complex effectively complements the standard rehabilitation methods for children with $\mathrm{CP}$, and suggest that its clinical effectiveness in individuals with $\mathrm{CP}$ may be proven by enrollment of more patients. Keywords: cerebral palsy, rehabilitation, brain-computer interface, hand exoskeleton, EEG
\end{abstract}

Funding: the study received public financial support from the Ministry of Science and Higher Education of the Russian Federation (project ID RFMEFI60519X0184). Author contribution: Bobrov PD - EEG processing and analysis, $\mathrm{BCl}$ accuracy estimation, manuscript writing; Biryukova EV — assessment scales scores statistical processing, manuscript writing; Polyaev BA, Lajsheva OA, Usachjova EL — clinical trial design; Usachjova EL — clinical trial management; Lajsheva OA, Sokolova AV, Mihailova DI, Dement'eva KN — development of methods for working with children, clinical data acquisition; Mihailova DI, Dement'eva KN — neuropsychological testing, training; Fedotova IR - literature analysis. All authors contributed to interpretation of the results and discussion.

Compliance with ethical standards: the study was approved by the Ethics Committee of Pirogov Russian National Research Medical University (protocol № 184 dated April 15, 2019). The informed consent was submitted by all patients' parents, adolescents aged over 14 submitted the additional informed consent.

$\varangle$ Correspondence should be addressed: Pavel D. Bobrov Ostrovitianova, 1, Moscow, 117997; p-bobrov@yandex.ru

Received: 31.07.2020 Accepted: 13.08.2020 Published online: 20.08.2020

DOI: 10.24075/brsmu.2020.047

\section{РЕАБИЛИТАЦИЯ БОЛЬНЫХ С ДЕТСКИМ ЦЕРЕБРАЛЬНЫМ ПАРАЛИЧОМ С ПОМОЩЬЮ ЭКЗОСКЕЛЕТА КИСТИ, УПРАВЛЯЕМОГО ИНТЕРФЕЙСОМ «МОЗГ-КОМПЬЮТЕР»}

П. Д. Бобров ${ }^{1,2}$, Е. В. Бирюкова ${ }^{1,2}$, Б. А. Поляев ${ }^{1}$, О. А. Лайшева ${ }^{1,3}$, Е. Л. Усачёва ${ }^{3}$, А. В. Соколова ${ }^{3}$, Д. И. Михайлова ${ }^{3}$, К. Н. Дементьева ${ }^{3}$, И. Р. Федотова

${ }^{1}$ Российский национальный исследовательский медицинский университет имени Н. И. Пирогова, Москва, Россия

2 Институт высшей нервной деятельности и нейрофизиологии, Москва, Россия

${ }^{3}$ Детская клиническая больница Российского национального исследовательского медицинского университета имени Н. И. Пирогова, Москва, Россия

\begin{abstract}
Детский церебральный паралич - одно из тяжелых заболеваний центральной нервной системы у детей, сопровождающееся двигательными нарушениями. Целью работы было определить эффективность применения комплекса, объединяющего интерфейс «мозг-компьютер» (ИМК) и экзоскелет кисти, в качестве средства восстановления двигательной функции у пациентов с ДЦП в дополнении к основной терапии. У 14 детей и подростков по шкалам ARAT, Fugl-Meyer, Jebsen-Taylor оценивали изменение двигательной функции в результате терапии, дополненной 7-10 процедурами с комплексом ИМК-эКзоскелет, а также исследовали свойства источников $\mu$-ритма ЭЭГ при воображении движений во время управления ИМК. После процедур были выявлены достоверно положительный прирост баллов по шкалам Fugl-Meyer (7 (2; 11) — для активных движений руки; 4,5 (1; 6) для проксимальных отделов и 2,5 (0; 5) - для кисти), ARAT (7,5 (1; 31) - для общей суммы баллов, 1,5 (0; 12$)$ - для шарового и 1,5 (0; 8) - для цилиндрического захвата) и достоверно отличное от нуля снижение времени выполнения трех из семи задач теста Jabsen-Taylor (-1 (-4,13; 0,25) - для имитации кормления; -1 (-2; 0) - для перестановки легких и тяжелых банок). Средняя вероятность правильного распознавания ИМК составила 0,51 $(0,45 ; 0,54)$ (max = 0,70). В большинстве записей ЭЭГ были выделены источники н-ритма, как в сохранном, так и в пораженном полушарии. Показано наличие десинхронизации н-ритма при воображении движений, от степени которой достоверно зависит точность работы ИМК. Результаты показывают, что применение комплекса ИМК-экзоскелет эффективно дополняет стандартную реабилитацию детей с ДЦП, а также дают основания предполагать, что ее клиническая эффективность в случае ДЦП может быть доказана с привлечением большего числа пациентов.
\end{abstract}

Ключевые слова: ДЦП, реабилитация, интерфейс «мозг-компьютер», экзоскелет кисти, электроэнцесалограмма

Финансирование: работа выполнена при финансовой поддержке государства в лице Минобрнауки России (идентификатор соглашения RFMEFI60519Х0184).

Вклад авторов: П. Д. Бобров - обработка и анализ ЭЭГ, оценка точности работы ИМК, написание статьи; Е. В. Бирюкова - статистическая обработка клинических шкал, написание статьи; Б. А. Поляев, О. А. Лайшева, Е. Л. Усачева - дизайн клинического исследования; Е. Л. Усачева - организация клинического исследования; О. А. Лайшева, А. В. Соколова, Д. И. Михайлова, К. Н. Дементьева - разработка методики работы с детьми, сбор клинических данных; Д. И. Михайлова, К. Н. Дементьева - нейропсихологическое обследование, тренинг; И. Р. Федотова - анализ литературы. Все авторы принимали участие в интерпретации результатов и обсуждении текста статьи.

Соблюдение этических стандартов: исследование одобрено этическим комитетом (протокол № 184 от 15 апреля 2019 г.), проведено согласно протоколу клинической апробации 2019-63-6, утвержденному экспертным советом Минздрава России. Родители всех пациентов подписали информированное согласие на участие в исследовании, дети старше 14 лет подписывали информированное согласие дополнительно к подписи родителей.

$\bigotimes$ Для корреспонденции: Павел Дмитриевич Бобров ул. Островитянова, д. 1, г. Москва, 117997; p-bobrov@yandex.ru

Статья получена: 31.07.2020 Статья принята к печати: 13.08.2020 Опубликована онлайн: 20.08.2020

DOI: $10.24075 /$ vrgmu.2020.047 